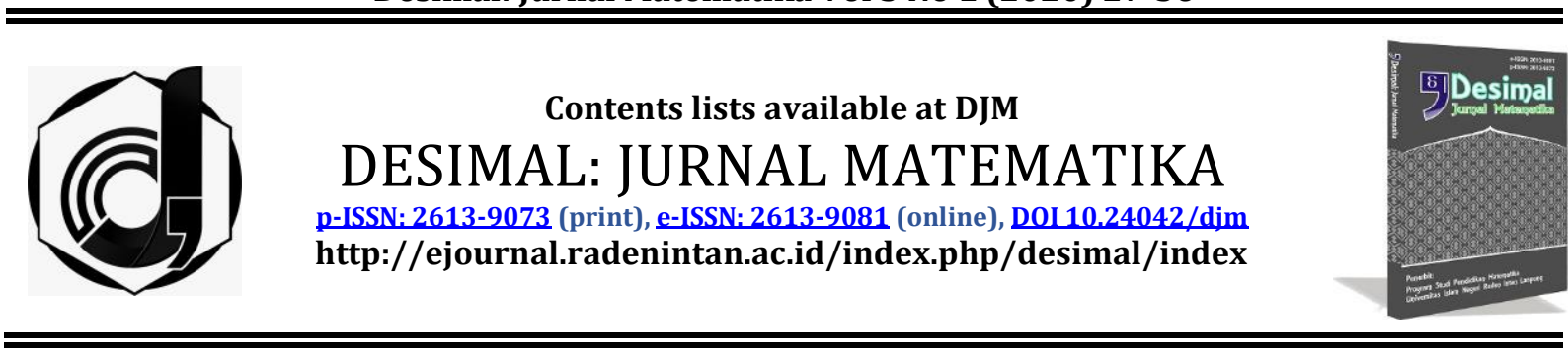

\title{
The Influence of Classroom Flipped Model and Heuristic Vee on Students' Understanding of Mathematical Concepts
}

\author{
Muhammad Syahrul1,*, Ummu Kalsum¹, Cindi Nadya Putri², Lilis Mardiyana ${ }^{2}$, Jutamat \\ Sutduean ${ }^{3}$ \\ ${ }^{1}$ Universitas Muslim Indonesia Makassar, Indonesia \\ 2 Universitas Islam Negeri Raden Intan Lampung, Indonesia \\ ${ }^{3}$ Dhurakij Pundit University, Thailand
}

\author{
ARTICLE INFO \\ Article History \\ Received : 19-09-2019 \\ Revised :22-11-2019 \\ Accepted :08-01-2020 \\ Published :26-01-2020 \\ Keywords: \\ Ability to understand \\ mathematical concepts \\ flipped classroom; \\ vee heuristics. \\ *Correspondence: E-mail: \\ m.syahrulfai@umi.ac.id \\ Doi:

\begin{abstract}
We already know that, there are many learning models that are used to improve the ability to understand mathematical concepts. In this study, researchers will use two learning models that have been previously studied. But this study is different from previous studies, this study aims to find a better model in improving the ability to understand students' mathematical concepts through test results by applying the flipped classroom and heuristic vee models. The method used in this study is quasi-experimental (quasiexperimental) and testing using the $\mathrm{T}$ and $\mathrm{N}$-Gain test. Based on the results of the data analysis conducted, it can be concluded that increasing the ability to understand mathematical concepts of students who use the flipped classroom learning model is far better than vee heuristics.
\end{abstract}

\section{INTRODUCTION}

Understanding mathematical concepts is very important to learn because in this 4.0 era it takes the ability of students who not only understand mathematics learning in general but rather the ability of students who can apply the concept appropriately and efficiently in the process of learning mathematics. The reason understanding of important concepts for students is the basis of knowledge which is the goal of early mathematics learning (Mulligan \& Mitchelmore, 2009). The application of constructivism approach with the help of macromedia flash 8, Group Investigation (GI), Student Teams Achievement Division (STAD) with Team Game Tournament (TGT), (discovery learning), Realistic Mathematical Approach (PMR) can improve students' concept understanding abilities (Muchlis \& Maizora, 2018) (Pranata, 2016) (Menanti \& Rahman, 2015) (Agustina, 2016). 
Learning mathematics does not only understand the concept or procedure, but many things can emerge from the results of the mathematics learning process(Habibi et al., 2019). Students are said to understand concepts if students are able to define concepts, identify and give examples or not examples of concepts, develop mathematical connection skills between various ideas, understand how mathematical ideas are related to each other so that a thorough understanding is built, and use mathematics in context outside of mathematics. (Istikomah \& Jana, 2018) An alternative selection of an appropriate learning approach can improve the ability to understand concepts(Rahmawati, Lestari, \& Umam, 2019), which is applied in everyday life (Saragih, 2018)(Istikomah \& Jana, 2018).

Referring to the current conditions, understanding of mathematical concepts is still fairly low. Therefore in this study, researchers will compare two learning models that are thought to improve the ability to understand mathematical concepts. The intended learning model is the flipped classroom model and vee heuristic model. Researchers take the flipped classroom model because the model is very flexible with current developments.

Flipped classroom is closely related to technology which in this era of globalization is very suitable for millennial children. From the results of previous studies revealed that the flipped classroom learning model can improve students' understanding of mathematical concepts (Saputra \& Mujib, 2018), on electricity and electronics (Hamid \& Effendi, 2019), building a culture of good interaction with all elements both among fellow teaching participants, with instructors, teaching materials and technology media(Hartinah et al., 2019), increase student motivation (Mubarok, 2017), influential in many fields (Sukmana \& Suartama, 2018), improve thinking skills (Maolidah, Ruhimat, \& Dewi, 2017), increase students' self-confidence (Pratiwi, Sahputra, \& Hadi, 2017), that this resulted into better learning (Aidinopoulou \& Sampson, 2017), and improve student communication skills (Widodo, 2017).

Researchers also take the heuristic vee model because in this model students are required to be active in experimenting and exploring. It was found that in previous studies heuristic vee models succeeded in increasing students' understanding of mathematical concepts (Riantini, Wisna Ariawan, \& Sariyasa, 2019), improve the ability to solve problems that are valid and effective (Putra, Purwanti, \& Khoiriyah, 2018), problem solving skill (Rahman, Murnaka, \& Wiyanti, 2018), affective student in plant material (Perdana, 2018), positive effect on learning outcomes (Suardita, Garminah, \& Renda, 2015), learning achievement (Hastuti, Mulyani, \& Indriyanti, 2019), find meaning of all knowledge (Wijayanti, Mahadewi, \& Parmiti, 2013), improve usability aspects (Ali Pramana Heuristik Vee, 2018), and online college websites (Hidayah, Yunita, \& Setyaningsih, 2019).

There is a lot of research that uses flipped classroom and heuristic vee models. Both of these models are not only used in mathematics, but also in various other fields (Munifah, Romadhona, et al., 2019). Based on existing research, we know that both models have the same influence in learning. Seen from the many studies that use both models, researchers want to prove which model is better to use(Lestari et al., 2019). This makes researchers want to continue previous research. The purpose of this article is to find out which model has a better impact on improving students' understanding of mathematical concepts between the 
Desimal, 3 (1), 2020 - 29

Muhammad Syahrul, Ummu Kalsum, Cindi Nadya Putri, Lilis Mardiyana, Jutamat Sutduean

flipped classroom model and the heuristic vee model.

\section{METHOD}

This study uses a quasi experimental reseach method (quasiexperimental). This research compares

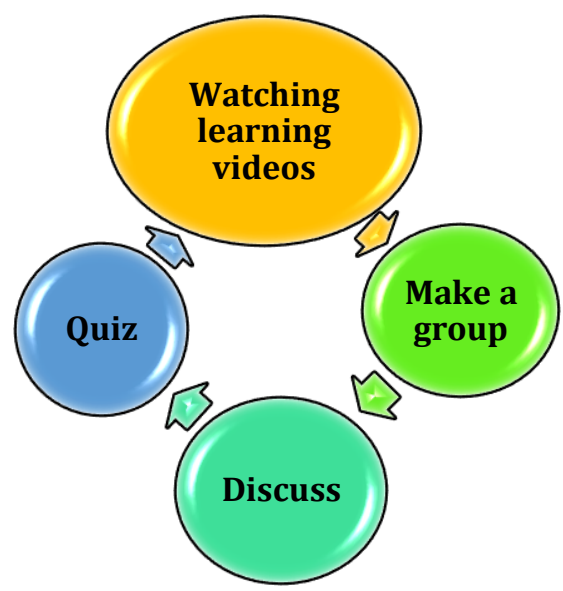

Figure 1. Flipped Classroom Model

Based on Figure 1, the first step is the teacher providing teaching material assisted with technology, for example, providing material in the form of video. then ask students to watch the learning video that has been given previously. Then the teacher forms students in groups to discuss. implementation of the discussion is carried out with a predetermined time and each student must understand the material that has been taught, because at the end of learning the teacher will take an assessment by conducting a quiz. After the learning discussion time is over, the teacher will give quiz questions to test the ability of each student at the end of the lesson.

Based on Figure 2, the first step taken at the beginning of learning is the teacher becomes the main focus, where the teacher explains the basic concepts, the object of discussion, and events in general. Next the teacher conveys the material delivered. There is an introduction to the meaning, followed by recording the material to arrive at the the experimental class with the flipped classroom model, and the experimental class with the heuristic vee model. The comparative design can be seen in Figure 1 and Figure 2.

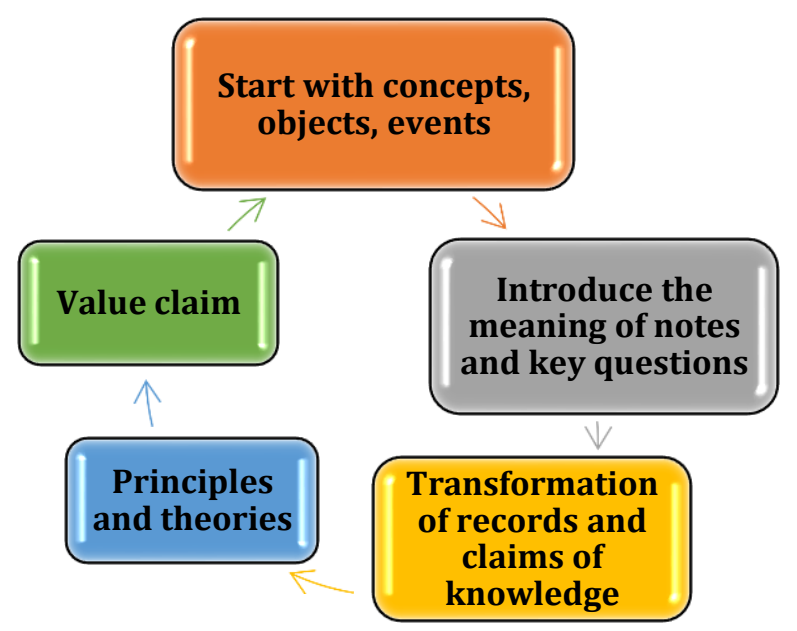

Figure 2. Vee Heuristic Model

question which becomes the main purpose of the material. The next step each student is asked to change the notes given by the teacher to be more detailed and explore the knowledge of the material being taught, by finding material using teaching resources. After getting more proven material accuracy, students must find theories that strengthen the material, so they can find the principles on which the material is based. At the end of the lesson the teacher will give a test to take a student assessment.

The independent variables in the study are the application of the flipped classroom model and the vee heuristic model. The dependent variable in this study is the ability to understand concepts. Data collection techniques are observation, test and documentation. Data analysis in this study was carried out using statistical analysis. The first step taken by researchers is to calculate the score of the pre-test and post-test results. To find out the increase in students' understanding of concept skills 
Muhammad Syahrul, Ummu Kalsum, Cindi Nadya Putri, Lilis Mardiyana, Jutamat Sutduean

can be calculated by the gain or difference in the results of pre-test and post-test. The second step is to test for normality to check the validity or normality of the sample and enter it to show that the sample data comes from a normally distributed population. The results of the normality test are needed as a prerequisite to determine the appropriate statistical hypothesis test. The normality test in this study, the data processing application program used is Statistical Product and Service Solution (SPSS) 24 with Kolmogorov Smirnov One-Sample normality test is if the sig value (significance) or probability value $<0.05$ then the distribution is not normal. Whereas if the sig value (significance) or probability value $>0.05$ then the distribution is normal. The third step is to test the hypothesis. Hypothesis testing is performed to determine acceptance or rejection of the hypothesis. In this study using the T test two groups of samples (independent sample test). In this study the $\mathrm{T}$ test was used to compare the results of pre-test and post-test classes using the flipped classroom model and classes using the vee heuristic model. Then the researchers calculate the effect to determine the level of effectiveness with the following formula:

$S_{g a b}=\sqrt{\frac{\left(n_{1}-1\right)\left(S_{1}^{2}\right)+\left(n_{2}-1\right)\left(S_{2}^{2}\right)}{n_{1}+n_{2}-2}}$ $\mathrm{d}=\frac{\bar{x}_{1}-\bar{x}_{2}}{S_{g a b}}$

Information :

Sgab : Combined variance of the flipped classroom class and the vee heuristic class

$\mathrm{n}_{1} \quad$ : The sample size of the flipped classroom experimental group

$\mathrm{n}_{2} \quad$ : The number of sample groups heeistic vee class experiment

$S_{1} \quad$ : Class variance of flipped classroom classes
$S_{2} \quad$ : Vee heuristic class group variance

d : Effect size

$\overline{x_{1}} \quad$ : Average group experimental class flipped classroom

$\overline{x_{2}} \quad$ : The average heuristic vee class experimental group

Table 1. Effect size, percentage and category

\begin{tabular}{ccc}
\hline Effect size & Percentage & Category \\
\hline $\mathbf{0 , 0}$ & $50 \%$ & Low \\
$\mathbf{0 , 1}$ & $54 \%$ & Low \\
$\mathbf{0 , 2}$ & $58 \%$ & Low \\
$\mathbf{0 , 3}$ & $62 \%$ & Low \\
$\mathbf{0 , 4}$ & $66 \%$ & Low \\
$\mathbf{0 , 5}$ & $69 \%$ & Low \\
$\mathbf{0 , 6}$ & $73 \%$ & Normally \\
$\mathbf{0 , 7}$ & $76 \%$ & Normally \\
$\mathbf{0 , 8}$ & $79 \%$ & Normally \\
$\mathbf{0 , 9}$ & $82 \%$ & High \\
$\mathbf{1 , 0}$ & $84 \%$ & High \\
$\mathbf{1 , 2}$ & $88 \%$ & High \\
$\mathbf{1 , 4}$ & $92 \%$ & High \\
$\mathbf{1 , 6}$ & $95 \%$ & High \\
$\mathbf{1 , 8}$ & $96 \%$ & High \\
$\mathbf{2 , 0}$ & $98 \%$ & High \\
$\mathbf{2 , 5}$ & $99 \%$ & High \\
$\mathbf{3 , 0}$ & $99,9 \%$ & High \\
\hline
\end{tabular}

\section{RESULTS AND DISCUSSION}

Based on the results of research that discusses the improvement of students' understanding of mathematical concepts obtained from the pre-test and post-test experimental classes that apply the flipped classroom learning model and experimental classes that apply the vee heuristic learning model so that the following research results are obtained. After obtaining the pre-test and post-test average results, it will obtain a gain or difference between the pretest and posttest scores to find out the increase in students' understanding of mathematical concepts. 
Desimal, 3 (1), 2020 - 22

Muhammad Syahrul, Ummu Kalsum, Cindi Nadya Putri, Lilis Mardiyana, Jutamat Sutduean

Table 2. Descriptive data between the flipped classroom model and the heuristic vee model

\begin{tabular}{lllllll}
\hline & Mean & Median & Varians & $\begin{array}{l}\text { Std. } \\
\text { Deviation }\end{array}$ & Maximum & Minimum \\
\hline $\begin{array}{l}\text { del Flipped } \\
\begin{array}{l}\text { Classroom } \\
\text { Model Heuristik Vee }\end{array}\end{array}$ & 60,0306 & 79,9979 & 34,919 & 5,90922 & 90 & 66,66 \\
\hline
\end{tabular}

Based on Table 2, descriptive data between the flipped classroom learning model and the vee heuristic learning model shows that the average flipped classroom model is better than the heuristic vee model. There is also a minimum value in the flipped classroom model better than the heuristic vee model. This shows that the flipped classroom model is better than the heuristic vee model in improving students' understanding of mathematical concepts.

After describing table 2 we get descriptive data in the form of mean, median, variance, standard deviation, maximum and minimum values. The study continued using an independent sample test to get the final conclusions on the study. The results of the independent sample test will be explained in Table 3.

Table 3. Independent Sample Test

\begin{tabular}{|c|c|c|c|c|c|c|}
\hline & & \multicolumn{2}{|c|}{$\begin{array}{l}\text { Levene's } \\
\text { Testforequality }\end{array}$} & \multicolumn{3}{|c|}{ t-test for equality of means } \\
\hline & & Varian & & & & \\
\hline \multirow{3}{*}{ N-Gain } & & $\mathrm{F}$ & Sig & $\mathrm{T}$ & Df & Sig (2-tailed) \\
\hline & equal variances assumed & 4,962 & 0,03 & 2,103 & 60 & 0,04 \\
\hline & equal variances not assumed & & 0,03 & 2,128 & 55,377 & 0,038 \\
\hline
\end{tabular}

Based on table 3 independent sample test found that:

Hypothesis testing

$\begin{array}{ll}\mathrm{H}_{0} & : \mu_{1} \leq \mu_{2} \\ \mathrm{H}_{1} & : \mu_{1}>\mu_{2} \\ \mu_{1} & : \text { Average flipped classroom }\end{array}$

learning model

$\mu_{2} \quad$ : Average heuristic learning model vee

Based on Table 2, obtained a Pvalue $<0.05$, then $\mathrm{H}_{0}$ in the hypothesis test is rejected. Thus it can be concluded that the flipped classroom model is better in improving students' understanding of mathematical concepts than the heuristic vee model.

Flipped classroom learning that occurs is students learn learning material at home in the form of text or video that has been uploaded to the internet by the teacher then when in class students and the teacher discusses things that are not understood by students from the results of learning at home or working on the exercises in class with the difficulty level of questions which is higher than when working on problems independently at home(Ramadhani, Umam, Abdurrahman, \& Syazali, 2019). The heuristic learning model vee is a method used to solve problems using the procedures of knowledge discovery knowledge. In accordance with previous researchers heirustik vee learning model is a learning model to assist students in understanding the structure of knowledge and the process of how knowledge is constructed, and shows that the development of peer tutoring learning tools with Heuristic Vee strategies to improve problem-solving abilities meet valid, practical and 
effective criteria (Ramadhani, Huda, \& Umam, 2019). The veur heuristic model emphasizes more students being able to build knowledge independently, students also gain meaningful learning that implies that various information learned will last longer in student memory.

Based on the results of the study showed that the flipped classroom model is better to use than the heuristic vee model. This is shown in the first step of the flipped classroom model using video or other technology-assisted teaching materials to make students interactive with the material to be taught (Munifah, Tsani, et al., 2019). In the vee heuristic model, the teacher is still the main instructor without intermediary media that makes students feel bored with the learning activities undertaken (Huda, Syahrul, Firmansyah, Ramadhani, \& Prasetiyo, 2019). It was also explained in the next step that the flipped classroom model invites more students to engage in discussion, but the purpose of the discussion wants students' individualistic abilities to produce individual abilities of students who are intelligent and active. In this study, researchers used an effect size calculation with the final result obtained 0.038 . Based on these data, the flipped classroom learning model has an effect of $50 \%$ on increasing the ability to understand students' mathematical concepts.

The results of this study are in line with the results of several previous studies namely the application of the flipped classroom model that affects learning outcomes, student motivation, critical thinking skills and various other fields. The veur heuristic model also influences learning outcomes, cognitive abilities, problem solving abilities, critical thinking, and improves aspects of usibility. However, based on our research it can be concluded that the flipped classroom model has a better impact on students' understanding of mathematical concepts than the heuristic vee model.

\section{CONCLUSIONS AND SUGGESTIONS}

Based on the results of the study concluded that the flipped classroom model is better than the heuristic vee model in improving students' understanding of mathematical concepts. Because the flipped classroom model becomes a model that is in harmony with the development of the current era and a model that can attract student learning interest. The flipped classroom model has a $50 \%$ effect on increasing the ability to understand students' mathematical concepts.

Researchers expect more teachers to apply the flipped classroom model as a learning model in school. Subsequent research that uses flipped classroom and heuristic vee, needs to be further investigated at different levels of education and on different material. In addition, this research will be better if it is complemented by looking at other factors that might have different effects on the results of the study.

\section{REFERENCES}

Agustina, L. (2016). Upaya Meningkatkan Kemampuan Pemahaman Konsep Dan Pemecahan Masalah Matematika Siswa Smp Negeri 4 Sipirok Kelas Vii Melalui Pendekatan Matematika Realistik (Pmr). EKSAKTA: Jurnal Penelitian Dan Pembelajaran MIPA, 1(1), 1-7.

Aidinopoulou, V., \& Sampson, D. G. (2017). An Action Research Study from Implementing the Flipped Classroom Model in Primary School History Teaching and Learning, 20, 237-247.

Habibi, B., Hartinah, S., Umam, R., Syazali, M., Lestari, F., Abdurrahman, A., \& Jauhariyah, D. (2019). Factor 
Desimal, 3 (1), 2020 - 33

Muhammad Syahrul, Ummu Kalsum, Cindi Nadya Putri, Lilis Mardiyana, Jutamat Sutduean

Determinants of Teacher Professionalism as Development of Student Learning Education at School of SMK PGRI in Tegal City, Indonesia. Journal of Gifted Education and Creativity, 6(2), 125134.

Hamid, A., \& Effendi, H. (2019). Flipped Classroom sebagai Alternatif Pembelajaran pada Mata Pelajaran Dasar Listrik dan Elektronika. JTEV : Jurnal Teknik Elektro Dan Vokasional (Edisi Elektronik), 5(1), 81-86.

Hartinah, S., Sholikhakh, R. A., Umam, R., Syazali, M., Andriani, S., Mujib, ... Lestari, F. (2019). Application Autoplay Media Studio (AMS) 8 for Learning Me-dia of Logaritm Function. International Journal of Engineering \& Technology, 8(2), In Press.

https://doi.org/10.14419/ijet.v7i4. 27914

Hastuti, T. W., Mulyani, B., \& Indriyanti, Y. (2019). Studi Komparasi Model Pembelajaran Problem Solving Hierarki dan Heuristik Terhadap Metakognisi pada Materi Stoikiometri Kelas X SMA N 4 Surakarta. Jurnal Pendidikan Kimia, 8(1), 85-93.

Hidayah, D. U., Yunita, I. R., \& Setyaningsih, G. (2019). Evaluasi Website Kuliah Online STMIK Amikom Purwokerto Menggunakan Metode Heuristik (Studi Kasus Mata Kuliah Enterprise Resource Management). MATRIK: Jurnal Manajemen, Teknik Informatika Dan Rekayasa Komputer, 18(2), 171179.

https://doi.org/10.30812/matrik.v $18 \mathrm{i} 2.360$

Huda, S., Syahrul, M., Firmansyah, M., Ramadhani, R., \& Prasetiyo, A. E. (2019). The Relationship between
Problem-Solving Ability and Students â€TM Characters Based on Islamic Perspectives. Tadris Jurnal Keguruan Dan Ilmu Tarbiyah, 4(2), 203-214. https://doi.org/10.24042/tadris.v4 i2.5299

Istikomah, D. A., \& Jana, P. (2018). Kemampuan pemahaman konsep matematis mahasiswa melalui pendekatan pembelajaran saintifik dalam perkuliahan aljabar matrik. Prosiding Seminar Nasional Pendidikan Matematika Etnomatnesia.

Lestari, F., Saryantono, B., Syazali, M., Saregar, A., Jauhariyah, D., \& Umam, R. (2019). Cooperative Learning Application with the Method of Network Tree Concept Map : Based on Japanese Learning System Approach. Journal for the Education of Gifted Young Scientists, 7(1), 1532.

https://doi.org/10.17478/jegys.47 1466

Maolidah, I. S., Ruhimat, T., \& Dewi, L. (2017). Efektivitas Penerapan Model Pembelajaran Flipped Classroom pada Peningkatan Kemampuan Berpikir Kritis Siswa. Educational Technologia, 3(2), 160170.

Menanti, H., \& Rahman, A. A. (2015). Perbandingan Kemampuan Pemahaman Konsep Matematika Siswa Menggunakan Model Pembelajaran Kooperatif Tipe Student Teams Achievement Division ( STAD ) dengan Team Game Tournament ( Tgt ) di SD Islam Khalifah. Bina Gogik: Jurnal Ilmiah Pendidikan Guru Sekolah Dasar, 2(1), 38-48.

Mubarok, A. (2017). Model Flipped Classroom dalam Memotivasi Belajar Siswa. In Seminar Nasional 
Desimal, 3 (1), 2020 - 34

Muhammad Syahrul, Ummu Kalsum, Cindi Nadya Putri, Lilis Mardiyana, Jutamat Sutduean

Teknologi Pembelajaran Dan Pendidikan Dasar 2017, 184-188.

Muchlis, E. E., \& Maizora, S. (2018). Upaya Meningkatkan Kemampuan Pemahaman Konsep Trigonometri Melalui Pendekatan Konstruktivisme dengan Berbantukan Macromedia Flash 8 Pada Mahasiswa Program Studi Pendidikan Matematika FKIP Universitas Bengkulu. Jurnal Riset Pendidikan Matematika Jakarta, 1(1), 39-44.

Mulligan, J., \& Mitchelmore, M. (2009). Awareness of pattern and structure in early mathematical development . Mathematics Education Research ... Awareness of Pattern and Structure in Early Mathematical Development. Mathematics Education Research Journal, 21(May), 33-49. https://doi.org/10.1007/BF03217 544

Munifah, M., Romadhona, A. N., Ridhona, I., Ramadhani, R., Umam, R., \& Tortop, H. S. (2019). How to Manage Numerical Abilities in Algebra Material? Al-Jabar: Jurnal Pendidikan Matematika, 10(2), 223232.

https://doi.org/10.1017/CB09781 107415324.004

Munifah, Tsani, I., Yasin, M., Tortop, H. S., Palupi, E. K., \& Umam, R. (2019). Management System of Education : Conceptual Similarity (Integration ) between Japanese Learning System and Islamic Learning System in Indonesia. Tadris Jurnal Keguruan Dan Ilmu Tarbiyah, 4(2), 159-170. https://doi.org/10.24042/tadris.v4 i2.4893

Perdana. (2018). 済無No Title No Title. Journal of Chemical Information and Modeling, 53(9), 1689-1699. https://doi.org/10.1017/CB09781 107415324.004
Pranata, E. (2016). Implementasi Model Pembelajaran Group Investigation ( GI ) Berbantuan Alat Peraga Untuk Meningkatkan Kemampuan Pemahaman Konsep Matematika. JPMI (Jurnal Pendidikan Matematika Indonesia), 1(1), 34-38.

Pratiwi, A., Sahputra, R., \& Hadi, L. (2017). Pengaruh Model Flipped Classroom Terhadap SelfConfidence dan Hasil Belajar Siswa SMAN 8 Pontianak. Jurnal Pendidikan Dan Pembelajaran Khatulistiwa, 6(11).

Putra, L. V., Purwanti, K. Y., \& Khoiriyah, I. S. A. (2018). Pembelajaran Matematika Model Tutor Sebaya dengan Strategi Heuristik Vee. JANACITTA Journal of Primary and Children's Education, 1(2), 38-44.

Rahman, I. S., Murnaka, N. P., \& Wiyanti, W. (2018). Pengaruh Model Pembelajaran Laps ( Logan Avenue Problem Solving ) - Heuristik Terhadap Kemampuan Pemecahan Masalah. Wacana Akademika: Majalah Ilmiah Kependidikan, 2(1), 48-60.

Rahmawati, R., Lestari, F., \& Umam, R. (2019). Analysis of the Effectiveness of Learning in the Use of Learning Modules Against Student Learning Outcomes. Desimal: Jurnal Matematika, 2(3), 233-240.

Ramadhani, R., Huda, S., \& Umam, R. (2019). Problem-Based Learning, Its Usability and Critical View as Educational Learning Tools. Journal of Gifted Education and Creativity, 6(3), 219-231.

Ramadhani, R., Umam, R., Abdurrahman, A., \& Syazali, M. (2019). The Effect Of Flipped-Problem Based Learning Model Integrated With LMS-Google Classroom For Senior High School Students. Journal for the Education of Gifted Young, 7(2), 137-158. 
Muhammad Syahrul, Ummu Kalsum, Cindi Nadya Putri, Lilis Mardiyana, Jutamat Sutduean

https://doi.org/https://doi.org/10. 17478/jegys.548350

Riantini, N. K., Wisna Ariawan, I. P., \& Sariyasa, S. (2019). Penerapan Model Pembelajaran Heuristik Vee untuk Meningkatkan Pemahaman Konsep Matematika Siswa Kelas XI AP4 SMK Negeri 2 Singaraja. Jurnal Pendidikan Matematika Undiksha, 9(2), 52. https://doi.org/10.23887/jjpm.v9i 2.19896

Saputra, M. E. A., \& Mujib, M. (2018). Efektivitas Model Flipped Classroom Menggunakan Video Pembelajaran Matematika terhadap Pemahaman Konsep. Desimal: Jurnal Matematika, 1(2), 173-179.

Saragih, S. (2018). Analisis Kemampuan Pemahaman Konsep Matematis dan Kemampuan Pemecahan Masalah Matematis Siswa SMP pada Materi Sistem Persamaan Linear Dua Variabel ( SPLDV ). Suska Journal of Mathematics Education, 4(1), 9-16. https://doi.org/10.24014/sjme.v3i 2.3897

Suardita, P., Garminah, N. N., \& Renda, N. T. (2015). Pengaruh Model Pembelajaran Heuristik-V Berbantuan Media Peta Konsep Terhadap Hasil Belajar IPA Kelas IV SD. MIMBAR PGSD Undiksha, 3(1).

Sukmana, A. I. W. I. Y., \& Suartama, I. K. (2018). Pengembangan Mobile Learning Berorientasi Model Pembelajaran Flipped Classroom pada Mata Kuliah. Journal of Education Technology, 2(1), 45-50.

Widodo, S. (2017). Peningkatan Komunikasi Matematis Mahasiswa Calon Guru SD melalui Implementasi Flipped Classroom. Euclid, 4(2), 790-798.

Wijayanti, L. R., Mahadewi, P. L., \& Parmiti, P. (2013). Pengaruh Model
Pembelajaran Heuristik Vee di Gugus XV Kecamatan Buleleng. MIMBAR PGSD Undiksha, 1(1). 
Desimal, 3 (1), 2020 - 36

Muhammad Syahrul, Ummu Kalsum, Cindi Nadya Putri, Lilis Mardiyana, Jutamat Sutduean 